\title{
Inter-individual variability in reproductive success and somatic growth in Cichlasoma dimerus (Heckel, 1840)
}

\author{
Tomás Horacio Delgadin ${ }^{1,2 \dagger}$, Daniela Irina Pérez Sirkin ${ }^{1,2 \dagger}$, Paola Julieta Karp ${ }^{1}$, \\ Mariana Fossati ${ }^{1}$ \& Paula Gabriela Vissio ${ }^{1,2, *}$
}

\footnotetext{
1 Laboratorio de Neuroendocrinología del Crecimiento y la Reproducción, DBBE, FCEN-UBA, Ciudad Universitaria, (C1428EGA) Buenos Aires, Argentina.

2 IBBEA, CONICET-UBA, Ciudad Universitaria, (C1428EGA) Buenos Aires, Argentina.

authors with equal contributions

* Corresponding author: pvissio@gmail.com
}

\begin{abstract}
Environmental factors and social interactions are known to affect somatic growth and reproduction in teleost fish. It has been described for Cichlasoma dimerus that only one pair is formed under a wide range of laboratory conditions. However, this was not observed in tanks composed of three males and three females, where multiple pair formation occurred. Thus, our objective was to evaluate somatic growth and reproductive performance in $C$. dimerus under this particular condition, in which more than one pair is expected to be formed. A clear sexual growth dimorphism, with males growing faster than females, and multiple pair formation, sometimes simultaneously, were observed. Both features were absent in previous studies with other aquaria structures. Additionally, there was a significant association between reproductive events and body size, where the bigger the fish, both male and female, the higher the number of reproductive events. Despite the sexual growth dimorphism, no differences were observed between males and females in IGF-I and GHR2 mRNA levels. The results obtained for this social species show a high inter-individual variability in the aquaria in regard to reproductive success and growth. This may have implications on experimental design, where a low level of heterogeneity between fish is desirable. If this variability is not taken into account, possible treatment effects may not be detected.
\end{abstract}

KEY WORDS: Body size, cichlids, growth dimorphism, reproductive events.

\section{INTRODUCTION}

In teleost fish somatic growth is affected by environmental factors such as variations in the photoperiod (VERA CRUZ \& BROWN, 2009), temperature (GABILLARD et al., 2005), social interactions and food availability (VERA CRUZ \& BROWN, 2007, 2009). Somatic growth is defined as a change in size over time. This can be assessed by measuring differences in length and/or weight, implying different physiological processes (BECKMAN, 2011). Therefore, somatic growth is presented in literature by diverse parameters such as difference between final and initial length or body weight, somatic growth rate and condition factor among others.
Growth is regulated by the growth hormone (GH)/ insulin-like growth factor-I (IGF-I) axis (DUAN, 1998; BJÖRNSSON et al., 2002; WOOD et al., 2005; REINECKE, 2010). GH acts directly on certain tissues and indirectly via endocrine or local IGF-I production (ROUSSEAU \& DUFOUR, 2007). GH exerts its actions by binding to specific receptors (GHRs). Two GHR types have been described: GHR1, which has been proposed to be the somatolactin receptor, and GHR2, the GH receptor (FUKADA et al., 2004, 2005). The liver is the primary source of circulating IGF-I, but its expression is well documented in other extrahepatic tissues with a possible local function (REINDL \& SHERIDAN, 2012). BECKMAN (2011) discusses the use of IGF-I as a possible indicator 
of somatic growth in fish and concludes that before using IGF-I as a growth index in a given situation, the concordance between IGF-I and growth should be tested in that particular situation.

Somatic growth heterogeneity is a characteristic present in many teleost fish (FERNANDES \& VOLPATO, 1993; STEFÁNSSON et al., 2000; VERA CRUZ \& BROWN, 2007). Social hierarchies, differences in feeding, and gender are factors that could affect somatic growth rates (JOBLING \& REINSNES, 1986; RILEY et al., 2002a; MANDIKI et al., 2004; VERA CRUZ \& BROWN, 2007; JI et al., 2011). Many vertebrate species establish social hierarchies with dominant and subordinate individuals. Several studies carried out in fishes show that dominant individuals aggressively defend their territory and are reproductively active (ELLIS, 1995; FERNALD \& HIRATA, 1977; SAPOLSKY, 2005; FERNALD, 2009; RYDER et al., 2009), with some social species showing a relationship between agonistic interactions and size (ABBOT et al., 1985; BEAUGRAND et al., 1996). Besides, it has been observed that social interactions and feeding hierarchies result in individual growth rate variations (JOBLING \& REINSNES, 1986; RILEY et al., 2002a; MANDIKI et al., 2004; VERA CRUZ \& BROWN, 2007; JI et al., 2011). In addition, it is well-known that certain fish species exhibit sexual dimorphism in somatic growth. For instance, in some species males grow faster than females, such as in the tilapia Oreochromis mossambicus (PETERS, 1852) (RILEY et al., 2002a), and in others females grow faster than males, such as half-smooth tongue sole Cynoglossus semilaevis (GÜNTHER, 1873) (JI et al., 2011) or Eurasian perch Perca fluviatilis (LINNAEUS, 1758) (MANDIKI et al., 2004). Several studies suggest that gonadal steroid hormones modulate the GH-IGF-I axis in fishes (RILEY et al., 2002b, ARSENAULT et al., 2004; LARSEN et al., 2004; MANDIKI et al., 2004; DAVIS et al., 2007, 2008).

Cichlasoma dimerus (HECKEL, 1840) is a South American cichlid fish that exhibits high growth rates under laboratory conditions. As many cichlids do, $C$. dimerus displays highly organized breeding activities, as can be observed in the laboratory. The dominant pair will aggressively defend the prospective spawning site (usually a flat stone) and will start to display stereotyped pre-spawning activities (PANDOLFI et al., 2009). In a pair, the male is bigger than the female. The somatic growth rate and the reproductive performance in a time period depend on the condition in which the fish are maintained. For example, in tanks composed of four males and four females only one pair is formed between a female and the biggest male in the aquaria (preliminary results of our laboratory and ALONSO et al., 2011). In these conditions we did not observe differences in somatic growth rate between genders. On the other hand, in tanks composed of three males and three females, multiple pairs are established (previous observation). Thereby, the aim of the present study was to evaluate somatic growth and sexual performance in fish maintained in tanks where more than a pair is expected to be formed.

\section{MATERIALS AND METHODS}

\section{Animals}

Adult $C$. dimerus were collected from "Esteros del Riachuelo", Corrientes, Argentina $\left(27^{\circ} 12^{\prime} 50^{\prime}\right.$ 'S, $\left.58^{\circ} 11^{\prime} 50^{\prime \prime} \mathrm{W}\right)$, transferred to the laboratory and acclimated in fresh water tanks (4001) under stable conditions of temperature $(25 \pm 3)^{\circ} \mathrm{C}$ and photoperiod (14 hours light:10 hours dark). Pairs of $C$. dimerus established in these tanks were withdrawn and maintained together in individual aquaria until their use in the experiment. During this time, fish were fed daily with commercial pellets (Tetra Pond Variety Blend, Tetra). A pair was considered formed after a reproductive event occurred. Suitable actions were followed to minimize pain or discomfort to fish. Principles of laboratory animal care (Guidelines on the care and the use of fishes in research, teaching and testing, Canadian Council on Animal Care, 2005) were adopted. Experiments comply with the approval 
of Comisión Institucional para el Cuidado y Uso de Animales de Laboratorio, Facultad de Ciencias Exactas y Naturales, Buenos Aires, Argentina (protocol number 26).

\section{Experimental protocol}

The experiment was carried out from November 2010 to May 2014. Each replication $(n=5)$ consisted of three pairs (the ones previously obtained) placed in a $400 \mathrm{~L}$ aquarium (density $=15 \mathrm{fish} / \mathrm{m}^{3}$ ) containing gravel, artificial plants and some slabs, under the same temperature and photoperiod conditions as described above. Initial body mass (BM, males: $18.57 \pm 1.1 \mathrm{~g}$; females: $14.77 \pm 1.08 \mathrm{~g})$ and total length $\left(\mathrm{L}_{\mathrm{T}}\right.$, males: $9.87 \pm$ $0.19 \mathrm{~cm}$; females: $9.20 \pm 0.24 \mathrm{~cm}$ ) were measured $(\mathrm{P}=0.07$ after MANOVA for differences in initial $\mathrm{L}_{\mathrm{T}}$ and $\mathrm{BM}$ ) immediately preceding the experiment. Animals were kept for two months under these experimental conditions and daily fed with the same commercial pellets. During this period, they were individually identified by their sizes and the particular spot pattern in their fins. Every day during 30 minutes, between 1112 AM, feeding behaviour, reproductive events and hierarchy status were visually registered. In addition, several times during the course of each experiment, a video recording was performed. Feeding behaviour, rather than food intake, was evaluated as the intention of the fish to catch a pellet. When these fish take a pellet into their mouths, they spit it out many times. Therefore it is not possible to directly quantify the amount of food actually ingested.

In order to evaluate a possible relationship between the number of reproductive events (defined as the egg spawning and the posterior fertilization by the males' sperm release) and initial body size, each fish per tank was classified according to its sex and initial BM or $\mathrm{L}_{\mathrm{T}}$. The smallest fish in a tank was ranked as number 1 , the next one as number 2 and the biggest one as number 3 . This classification was carried out for males and females separately.

\section{Tissue sample and transcripts quantification}

After a two months span, $\mathrm{BM}$ and $\mathrm{L}_{\mathrm{T}}$ were measured. Fish were anesthetized with benzocaine $0.1 \%$, euthanized by decapitation, and livers collected. As indicators of the nutritional status, hepatosomatic index $\left(\mathrm{I}_{\mathrm{H}}=\right.$ organ mass/body mass*100) and condition factor $\left(\mathrm{CF}=\mathrm{BM}^{*}\left(\mathrm{~L}_{\mathrm{T}}\right)^{-3 *} 100\right)$ were calculated. For evaluating growth in each fish during the two months experiment $\Delta \mathrm{L}_{\mathrm{T}}$ (final $\mathrm{L}_{\mathrm{T}}$ - initial $\mathrm{L}_{\mathrm{T}}$ ), $\triangle \mathrm{BM}$ (final BM - initial BM) and specific growth rate (SGR) were calculated. SGR is defined as $\mathrm{Ln}(\mathrm{Xf} / \mathrm{Xi}) * \mathrm{t}^{-1 *} 1000$, where $\mathrm{t}$ is time measured in days and $\mathrm{Xf}$ and $\mathrm{Xi}$ denote $\mathrm{BM}$ or $\mathrm{L}_{\mathrm{T}}$ at final and initial moment of the experiment, respectively.

Total liver RNA of 16 fish from three tanks was obtained by TRIzol ${ }^{\circledR}$ (Invitrogen) following manufacturer's instructions, and the corresponding cDNA was synthesized in order to quantify the different transcripts by quantitative real-time polymerase chain reaction (RTqPCR). RT-qPCRs for IGF-I, GHR2 and acidic ribosomal phosphoprotein P0 (ARP) (reference gene) were performed by using FastStart Universal SyBR green Master (ROCHE) with a mixture of forward and reverse specific primers (Table 1) and $2.5 \mu 1$ of cDNA template per tube. The RT-qPCR protocol was as follows: $10 \mathrm{~min}$ of denaturation at $95^{\circ} \mathrm{C}$ and 40 cycles of $95^{\circ} \mathrm{C}$ for $15 \mathrm{sec}, 58^{\circ} \mathrm{C}$ for $30 \mathrm{sec}$ and $72^{\circ} \mathrm{C}$ for $20 \mathrm{sec}$.

\section{TABLE 1}

Primers used for Real Time qPCR.

\begin{tabular}{|l|l|}
\hline \multicolumn{1}{|c|}{ Name } & \multicolumn{1}{|c|}{ Sequence (5' to 3') } \\
\hline GHR2 forward & ACTGCTCTCCACTCTCAATTG \\
GHR2 reverse & AAAGGTGATGGTTCTGGGTC \\
IGF-I forward & CTCCCAAGATTTCTCGCTCTG \\
IGF-I reverse & CCCTTCTCCGCTTTACTAACC \\
ARP forward & ACTGTGGGAGCAGACAATG \\
ARP reverse & TCCAGTGCAGGATTGTTCTC \\
\hline
\end{tabular}




\section{Statistical analysis}

Differences in mean total length $\left(\Delta \mathrm{L}_{\mathrm{T}}\right)$ and body mass $(\triangle \mathrm{BM})$ between genders were evaluated by using a Randomized Block Design (RBD) ANOVA considering the fixed factor gender and the random factor experimental replication (i.e, each tank). In order to discard any influence of the initial body size on growth performance between genders, Pearson's correlations between initial $\mathrm{L}_{\mathrm{T}}$ against $\Delta \mathrm{L}_{\mathrm{T}}$ and $\mathrm{BM}$ against $\Delta \mathrm{BM}$ for each sex were performed. For statistical analysis a single value per sex was used by averaging three fish per tank to avoid pseudo-replication. A Spearman's correlation was run to determine the relationship between reproductive events and body size ranks.

Raw qPCR data were submitted to LinRegPCR software processing in order to obtain initial fluorescence values per sample for subsequent analysis (RAMAKERS et al., 2003; RUIJTER et al., 2009). Pearson's correlations were used to evaluate possible associations between IGF-I mRNA levels and $\triangle \mathrm{BM}, \Delta \mathrm{L}_{\mathrm{T}}$ and SGRs. IGF-I and GHR2 mRNA levels between genders were analyzed by using a RBD ANOVA as it was done for morphometric parameters.
Values are expressed as means \pm S.E.M. Statistical tests were considered significant when p-values were less than 0.05 by using InfoStat $/ \mathrm{L}$ software. Sequential Bonferroni's correction was applied to keep the type I family-wise error rate at 0.05 level.

\section{RESULTS}

\section{Morphometric parameters}

$\Delta \mathrm{L}_{\mathrm{T}}$ and $\triangle \mathrm{BM}$ were significantly higher in males than in females $(0.60 \pm 0.09 \mathrm{~cm} v s .0 .16 \pm$ $0.07 \mathrm{~cm}, \mathrm{P}=0.0034)$ and $(4.32 \pm 0.95 \mathrm{~g} v s .0 .90$ $\pm 0.26 \mathrm{~g}, \mathrm{P}=0.0285$ ), respectively (Fig. 1a,b). For the sizes assessed in this experiment, we did not find any significant correlations between initial body size and $\Delta \mathrm{L}_{\mathrm{T}}$ or $\triangle \mathrm{BM}$ (Pearson's correlation, $\mathrm{P}>0.05)$. In addition, $\mathrm{SGR}\left(\mathrm{L}_{\mathrm{T}}\right)$ was significantly higher in males than in females (1.36 \pm 0.32 vs. $0.32 \pm 0.15$ respectively, $\mathrm{P}=0.0194$ ). Although $\triangle \mathrm{BM}$ was higher in males than in females, the differences for the SGR(BM) were not statistically significant $(3.49 \pm 1.46$ vs. 0.96 \pm 0.31 respectively, $\mathrm{P}=0.1298$ ). Even though females had a higher $\mathrm{I}_{\mathrm{H}}$, the difference between genders was not significant (males: $1.37 \pm 0.11 \%$ (a)

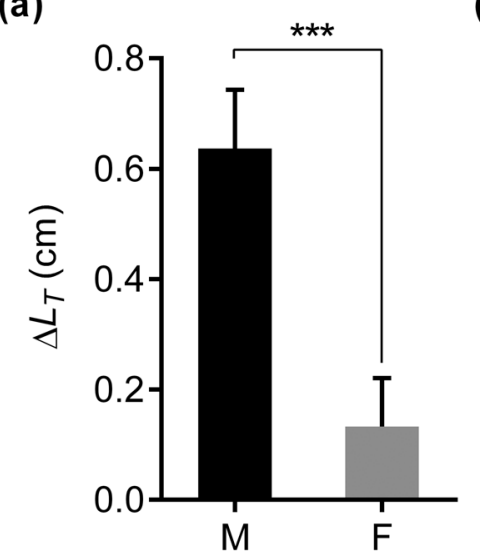

(b)

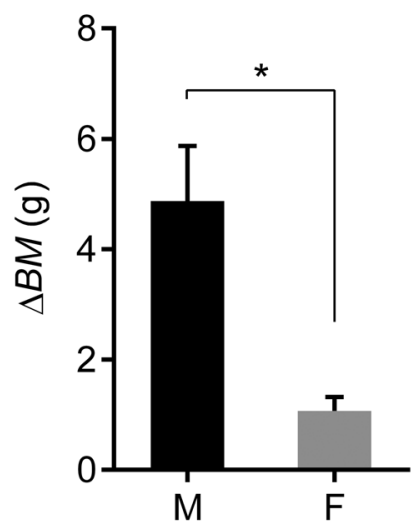

(c)

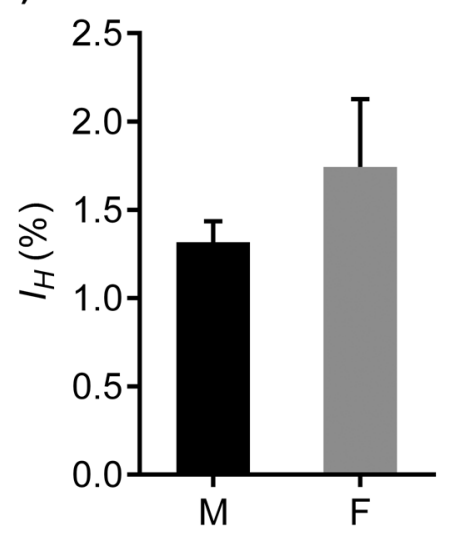

Fig. 1. - Morphometric parameters in three-pair tanks. Vertical bars represent the mean gain in (a) total length $\left(\Delta \mathrm{L}_{\mathrm{T}}\right),(\mathrm{b})$, body mass $(\Delta \mathrm{BM})$ and $(\mathrm{c})$ hepatosomatic index $\left(\mathrm{I}_{\mathrm{H}}\right)$. M: males; F: females. Results are presented as mean \pm SEM. $* * * P<0.001$. 
vs females: $1.78 \pm 0.30 \%, \mathrm{P}=0.3146$ ) (Fig. 1c) nor was it for $\mathrm{CF}$ (males: $1.81 \pm 0.08 v s$ females: $1.87 \pm 0.11, \mathrm{P}=0.7579)$.

\section{Reproductive performance}

As expected for this species, we observed aggressive behaviour of the reproductive pair defending the spawning site. This behaviour continued during the reproductive event and the period of parental care.

In all the replications, as was expected from previous observations, more than one pair was observed during the experimental period. Those pairs were not stable, which means that after the reproductive event a new pair was formed, including one or both of these individuals. On some occasions, two pairs were present simultaneously. There was a strong positive monotonic correlation between reproductive events and the initial body size ranking for males (Spearman's correlation, $\mathrm{L}_{\mathrm{T}}$ ranking: $\mathrm{r}_{\mathrm{s}}=0.78$, $\mathrm{P}=0.0011$; $\mathrm{BM}$ ranking: $\mathrm{r}_{\mathrm{s}}=0.85, \mathrm{P}=0.0001$ ) and females (Spearman's correlation, $\mathrm{L}_{\mathrm{T}}$ ranking: $r_{s}=0.69, \mathrm{P}=0.0048$; $\mathrm{BM}$ ranking: $\mathrm{r}_{\mathrm{s}}=0.69, \mathrm{P}$ $=0.0048)$. The greater number of reproductive events was associated with the larger fish present in every tank for both genders (Fig. 2). In all the replications, the first pair involved the biggest male. Initial pairs, established before the beginning of the experiment, were not necessarily maintained.

Additionally, video recordings suggested no difference in feeding behaviour among fish of the same tank. Even during the reproductive event and parental care, the pair showed similar feeding behaviour to the other fish in the tank.

\section{Hepatic IGF-I and GHR2 mRNA expression}

There was no difference in hepatic IGF-I mRNA levels $(\mathrm{P}>0.05$, Fig. 3a) nor in GHR2 mRNAlevels $(\mathrm{P}>0.05$, Fig. $3 \mathrm{~b})$ between genders. No correlations between hepatic IGF-I mRNA levels and $\triangle \mathrm{BM}, \Delta \mathrm{L}_{\mathrm{T}}$ and $\mathrm{SGR}$ were observed (Pearson's correlation, $\mathrm{P}>0.05$ ). (a)

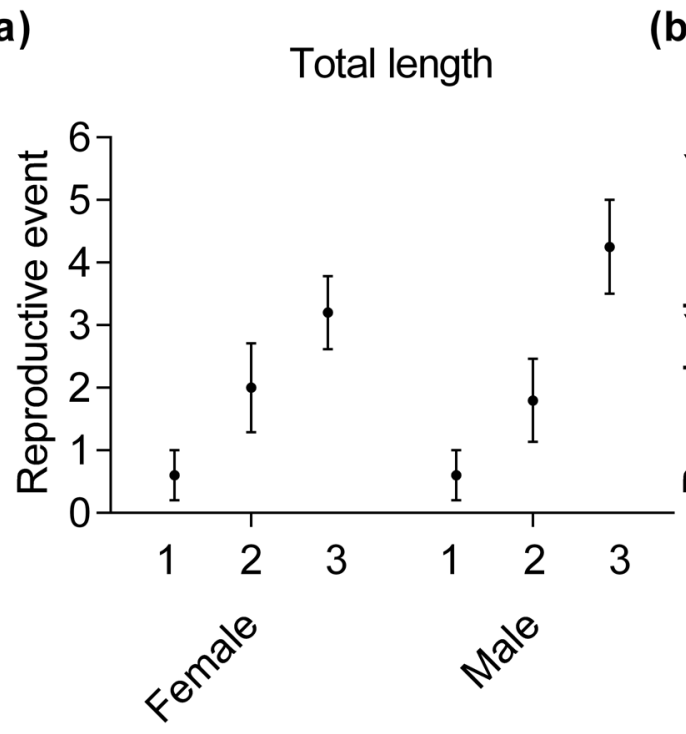

(b)

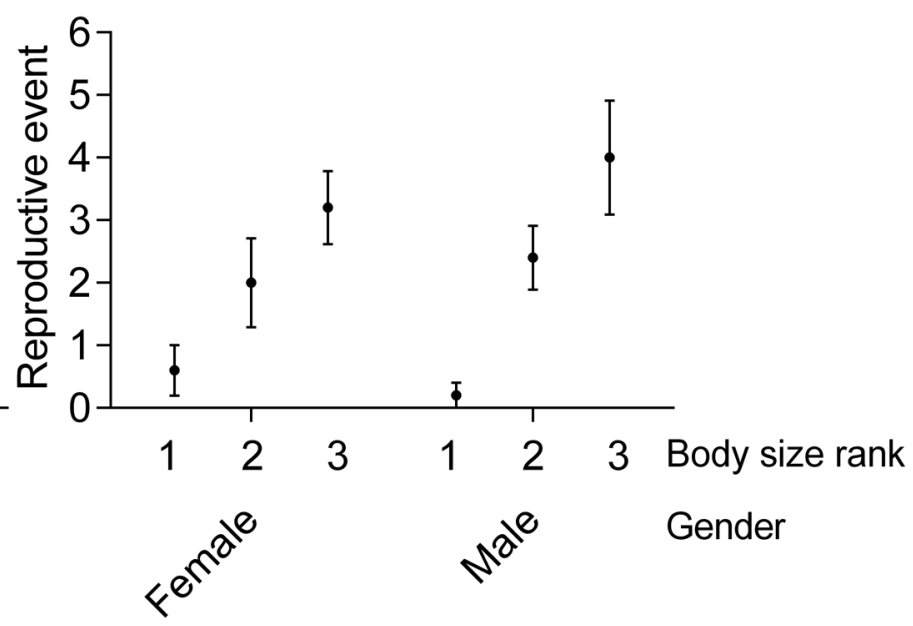

Fig. 2. - Relationship between reproductive events and the body size ranks. For both genders a greater number of reproductive events was associated with the larger fish present in every tank. Spearman's correlation was significant for total length (a) and body mass (b) both in males and females. Fish were ordered according to body size: 1: small; 2: intermediate; 3: big. Results are presented as mean \pm SEM 
(a)

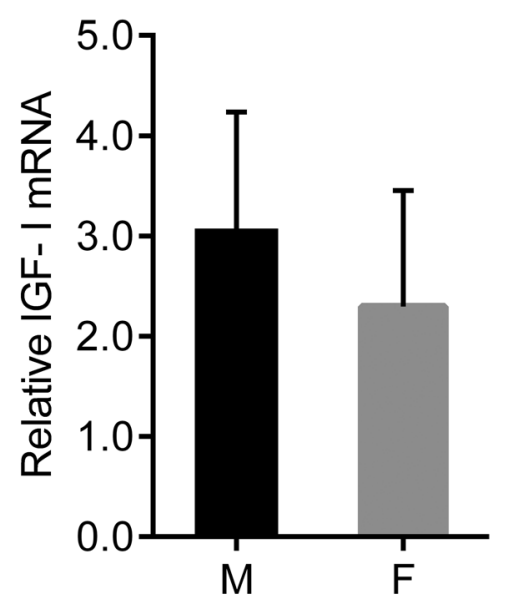

(b)

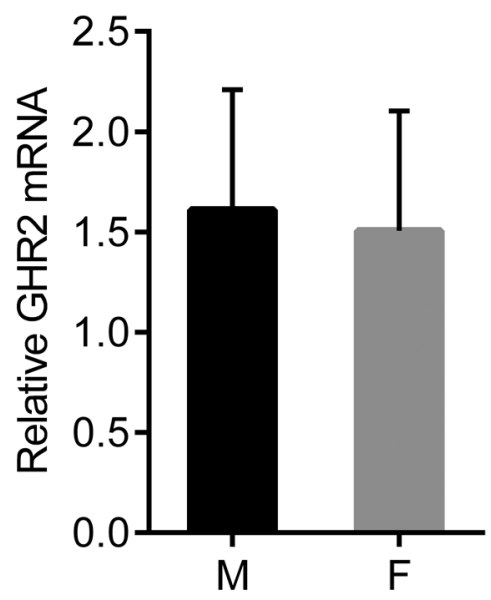

Fig. 3. - Hepatic IGF-I (a) and GHR2 (b) mRNA levels in males and females from three-pair tanks. Data were normalized using ARP as a reference gene and presented as a mean \pm SEM. No differences were observed in IGF-I and GHR2 mRNA levels between genders after an RBD ANOVA test. M: males; F: females.

\section{DISCUSSION}

Heterogeneous somatic growth is a common characteristic in fish populations (FERNANDES \& VOLPATO, 1993; STEFÁNSSON et al., 2000; VERA CRUZ et al., 2007). For instance, differences in somatic growth between dominants and subordinates (KOEBELE, 1985; VERA CRUZ \& BROWN, 2007) or between genders (RILEY et al., 2002a; DAVIS et al., 2008) have been described for many cichlid fish species. In this study, sexual growth dimorphism was clearly demonstrated by evaluating the difference between sexes in body mass and total length gain after two months of experiment. This comparison showed that males grew more than females. However, as $\triangle \mathrm{BM}$ and $\Delta \mathrm{L}_{\mathrm{T}}$ can be influenced by their values at the beginning of the experiment, we also compared their SGR values. These results are in line with those obtained with $\Delta \mathrm{BM}$ and $\Delta \mathrm{L}_{\mathrm{T}}$, showing that males display higher specific growth rates, statistically significant at least regarding length, compared to females. Additionally, we demonstrated that for the fish sizes used in this study, there was no relationship between the initial body size and $\Delta \mathrm{BM}$ or $\Delta \mathrm{L}_{\mathrm{T}}$ for each sex, which therefore excludes the possibility of any influence of the initial body size on growth performance. Taken together, these results give strong evidence for sexual growth dimorphism in $C$. dimerus.

A role of steroids in the promotion of somatic growth has been studied in several species. In fishes in which males grow more than females, administration of androgens promotes growth and an increment in IGF-I (RILEY et al., 2002a, b) whereas estradiol (E2) decreases it. In contrast, in those fishes in which females grow more than males, E2 would promote growth (MALISON et al., 1985; MALISON et al., 1988; HAYWARD et al., 2001) and also an increase in IGF-I (GOETZ et al., 2009). Additionally, in Eurasian perch $P$. fluviatilis, androgens produced a decrease in growth (MANDIKI et al., 2004). In the present study fish were in different reproductive states at the end of the experiment; gonodal steroids were therefore not measured due to the high variability expected. The question is, why was a 
clear sexual growth dimorphism observed in our experimental design? One possibility is that the sexual growth dimorphism was due to differences in food intake between males and females. However, this scenario seems to be unlikely as no apparent differences in feeding behaviour were observed. Moreover, the nutritional status parameters, hepatosomatic index and condition factor, were not different between genders. In our experiments fish were fed daily and food availability was never restricted, which should exclude the possibility of inequality in food availability. Another possibility could be a differential feed efficiency conversion between males and females and/or a bigger requirement of metabolic energy for reproduction in females, which would impact negatively on growth rate (MANDIKI et al., 2004). Specific experiments would be necessary to elucidate if the sexual growth dimorphism is due to differences in food intake and/or feed efficiency conversion.

Additionally, reproductive performance also depends on the tank conditions. Multiple pair formation was observed when three pairs were placed in the aquaria, a feature absent in fourpair tanks (preliminary results of our laboratory and ALONSO et al., 2011). The first pair formed always included the biggest male. Interestingly, in all tanks a strong correlation between reproductive events and body size was observed, where the bigger the fish, both male and female, the higher the number of reproductive events. To our knowledge this is the first report describing this association. In other reports, a positive correlation was observed between body size and fecundity success, but in those cases fecundity success was inferred as testis mass (PUJORAL et al., 2012), number of eggs per ovary (HOSSAIN et al., 2012) and sperm content (WATANABE et al., 2008). While gonadal parameters are widely used as indicators for fecundity, this does not necessarily imply new offspring because it depends on other events such as pair establishment and quality of the gametes among others. Unlike those approaches, our results show strong evidence on this issue.

In view of the somatic growth dimorphism observed, we investigated if there were changes in somatic growth axis that could explain this morphometric result. Unfortunately we could not measure $\mathrm{GH}$ expression in all the pituitaries due to technical issues during RNA extraction. In order to test if in $C$. dimerus a positive relationship exists between hepatic IGF-I mRNA and somatic growth, these parameters were compared in females and males. No correlation was observed between growth and IGF-I levels. Our results are in accordance with those obtained in chinook salmon Oncorhynchus tshawytscha (WALBAUM, 1792) and barramundi Lates calcarifer (BLOCH, 1790) (SILVERSTEIN et al., 1998; NANKERVIS et al., 2000). As summarized by Beckman (2011, p. 236-237), there are different relationships between IGF-I levels and somatic growth. In the present work hepatic IGF-I mRNA was measured at the end of the experiment i.e. at a specific time point. Unfortunately, it was impossible to measure IGF-I plasma levels due to the small plasma sample obtained. A possible scenario would have been to measure plasma IGF-I during the experiment (longitudinal design) but this kind of experimental design would have impacted negatively on the reproductive behaviour. Also, another component of the somatic growth axis, GHR2 was measured. No differences were observed in hepatic GHR2 mRNA levels, in agreement with no variations in IGF-I between genders. This result differs from that obtained in the Mozambique tilapia $O$. mossambicus (DAVIS et al., 2008) where males, which present greater somatic growth rates than females, showed higher level expression for both GHR1 and GHR2 mRNA receptors in the liver. Although in $C$. dimerus there were no differences at the expression level, possible differences at the protein level cannot be ruled out. More studies including measurements of plasma IGF-I and analysis of hepatic GHR2 content are necessary to check this out. 


\section{CONCLUSIONS}

In summary, this work shows clear sexual growth dimorphism in fish held in tanks containing three males and three females, and a significant association between reproductive events and body size. These results have implications in the design of laboratory experiments because it is a common practice to sample fish from a tank irrespective of social interactions that could be affecting critical parameters such as somatic growth or reproductive performance.

\section{ACKNOWLEDGEMENTS}

This work was supported by Agencia Nacional de Promoción Científica y Tecnológica (grant number: PICT 2008-2005. P.V.) and CONICET (grant number: PIP: 0276. P.V.).

\section{REFERENCES}

AbBotT JC, DUNBRACK RL \& ORR CD (1985). The interaction of size and experience in dominance relationship of juvenile steelhead trout (Salmo gairdneri). Behaviour, 92:241-253.

Alonso F, Cánepa M, Guimarães Moreira R \& PANDOLFI M (2011). Social and reproductive physiology and behaviour of the social cichlid fish Cichlasoma dimerus under laboratory conditions. Neotropical Ichthyology, 9:559-570.

ARSENAULT JT, FAIRCHILD WL, MACLATCHY DL, BURRIDGE L, HAYA K \& BROWN SB (2004). Effects of water-borne 4-nonylphenol and 17beta-estradiol exposures during parr-smolt transformation on growth and plasma IGF-I of Atlantic salmon (Salmo salar L.). Aquatic Toxicology, 66:255-265.

Beaugrand JP, PayetTe D \& Goulet C (1996). Conflict outcome in male green swordtail fish dyads (Xiphophorus helleri): interaction of body size, prior dominance/subordination experience, and prior residency. Behaviour, 133:303-319.

BECKMAN BR (2011). Perspectives on concordant and discordant relations between insulin-like growth factor 1 (IGF1) and growth in fishes. General and Comparative Endocrinology, 170:233-252.
BJÖRNSSON BT, JOHANSSON V, BENEDET S, EINARSDOTTIR IE, HiLDAhL J, AgUSTSSON $\mathrm{T}$ \& JÖNSSON E (2002). Growth hormone endocrinology of salmonids:Regulatory mechanisms and mode of action. Fish Physiology and Biochemistry, 27:227-242.

DAVIS LK, HiRAMATSU N, HiRAMATSU K, READING BJ, Matsubara T, Hara A, Sullivan CV, Pierce AL, Hirano T \& GraU EG (2007). Induction of three vitellogenins by 17betaestradiol with concurrent inhibition of the growth hormone-insulin-like growth factor 1 axis in a euryhaline teleost, the tilapia (Oreochromis mossambicus). Biology of Reproduction, 77:614625.

Davis LK, Pierce Al, Hiramatsu N, Sullivan CV, HIRANO T \& GRAU EG (2008). Gender-specific expression of multiple estrogen receptors, growth hormone receptors, insulin-like growth factors and vitellogenins, and effects of 17 beta-estradiol in the male tilapia (Oreochromis mossambicus). General and Comparative Endocrinology, 156:544-551.

DUAN C (1998). Nutritional and developmental regulation of insulin-like growth factors in fish. Journal of Nutrition, 128:306-314.

ELLIS L (1995). Dominance and reproductive success among nonhuman animals:a cross-species comparison. Ethology and sociobiology, 16:257333.

FERNALD RD \& HIRATA NR (1977). Field study of Haplochromis burtoni:quantitative behavioral observations. Animal Behaviour, 25:964-975.

FERNALD RD (2009). Social regulation of Reproduction: What changes and why? In: PFAFF DW, ARNOLD AP, ETGEN AM, FAHRBACH SE \& RUBIN RT (eds), Hormones, Brain and Behavior, 2nd edition, Vol. 1. Academic Press, San Diego:683-691.

FERNANDES M \& VOLPATO GL (1993). Heterogeneous growth in the Nile tilapia:Social stress and carbohydrate metabolism. Physiology \& Behavior, 54:319-323.

Fukada H, Ozaki Y, Pierce AL, Adachi S, YAMAUCHI K, HARA A, SWANSON P \& DiCKHOFF WW (2004). Salmon growth hormone receptor: molecular cloning, ligand specificity, and response to fasting. General and Comparative Endocrinology, 139:61-71.

Fukada H, OZAKI Y, PIERCE AL, ADACHI S, YAMAUCHI K, HARA A, SWANSON $\mathrm{P}$ \& 
DICKHOFF WW (2005). Identification of the salmon somatolactin receptor, a new member of the cytokine receptor family. Endocrinology, 146:2354-2361.

Gabillard JC, Weil C, Rescan Py, Navarro I, Gutierrez J \& LE BAIL PY (2005). Does the GH/IGF system mediate the effect of water temperature on fish growth? A review. Cybium, 29:107-117.

GoETZFW, Rise ML, Rise M, GoETZGW, BINKOWSKI F \& SHEPHERD BS (2009). Stimulation of growth and changes in the hepatic transcriptome by 17beta-estradiol in the yellow perch (Perca flavescens). Physiological Genomics, 38:261-280.

HAYWARD RS \& WANG N (2001). Failure to induce over-compensation of growth in maturing yellow perch. Journal of Fish Biology, 59:126-140.

HOSSAIN Y, RAHMAN M \& ABDALLAH EM (2012). Relationships between Body Size, Weight, Condition and Fecundity of the Threatened Fish Puntius ticto (Hamilton, 1822) in the Ganges River, Northwestern Bangladesh. Sains Malaysiana, 41:803-814.

JI XS, LIU HW, CHEN SL, JIANG YL \& TIAN YS (2011). Growth differences and dimorphic expression of growth hormone $(\mathrm{GH})$ in female and male Cynoglossus semilaevis after male sexual maturation. Marine Genomics, 4:9-16.

JoBLING M \& REINSNES TG (1986). Physiological and social constraints on growth of Arctic charr, Salvelinus alpinus L.: an investigation of factors leading to stunting. Journal of Fish Biology, 28:279-384.

KoEBELE BP (1985). Growth and the size hierarchy effect: an experimental assessment of three proposed mechanisms; activity differences, disproportional food acquisition, physiological stress. Environmental Biology of Fishes, 12:181188.

LARSEN DA, SHIMIZU M, COOPER KA, SWANSON P $\&$ DickHOFF WW (2004). Androgen effects on plasma GH, IGF-I, and 41-kDa IGFBP in coho salmon (Oncorhynchus kisutch). General and Comparative Endocrinology, 139:29-37.

MALISON JA, Best C, KAYES TB, AMUNDSON CH\& WentwORTH BC (1985). Hormonal growth promotion and evidence for a size-related difference in response to estradiol-17beta in yellow perch (Perca flavescens). Canadian Journal of Fisheries and Aquatic Sciences, 42:1627-1633.
MALISON JA, KAYES TB, WENTWORTH BC \& AMUNDSON CH (1988). Growth and feeding responses of male versus female yellow perch (Perca flavescens) treated with estradiol-17beta. Canadian Journal of Fisheries and Aquatic Sciences, 45:1942-1948.

MANDiKi SN, Houbart M, BABIAK I, VANDELOISE E, GARDEUR JN \& KESTEMONT P (2004). Are sex steroids involved in the sexual growth dimorphism in Eurasian perch juveniles? Physiology \& Behavior, 80:603-609.

NANKERVIS L, MATTHEWS SJ \& APPLEFORD P (2000). Effect of dietary non-protein energy source on growth, nutrient retention and circulating insulin-like growth factor I and triiodothyronine levels in juvenile barramundi, Lates calcarifer. Aquaculture, 191:323-335.

PANDOlfi M, CÁNePA MM, MeiJide FJ, Alonso F, Rey VÁzquez G, MAgGese MC \& Vissio PG (2009). Studies on the reproductive and developmental biology of Cichlasoma dimerus (Percifomes, Cichlidae). Biocell, 33:1-18.

PuJOLAR JM, LOCATELlo L, ZANE L \& MAZZOLDI C (2012). Body size correlates with fertilization success but not gonad size in grass goby territorial males. PLoS One, 7:e46711.

RAMAKERS C, RUIJTER JM, DEPREZ RH \& MOORMAN AF (2003). Assumption-free analysis of quantitative real-time polymerase chain reaction (PCR) data. Neuroscience Letters, 339:62-66.

REINDL KM \& SHERIDAN MA (2012). Peripheral regulation of the growth hormone-insulin-like growth factor system in fish and other vertebrates. Comparative Biochemistry and Physiology Part A: Molecular \& Integrative Physiology, 163:231245.

REINECKE M (2010). Insulin-like growth factors and fish reproduction. Biology of Reproduction, 82:656-661.

RILEY LG, HiRANO T \& GRAU EG (2002a). Disparate effects of gonadal steroid hormones on plasma and liver mRNA levels of insulin-like growth factor -I and vitellogenin in the tilapia, Oreochromis mossambicus. Fish Physiology and Biochemistry, 26:223-230.

RiLEy LG, Richman NH, HiRANO T \& GRAU EG (2002b). Activation of the growth hormone/ insulin-like growth factor axis by treatment with $17 \alpha$-methyltestosterone and seawater rearing in the tilapia, Oreochromis mossambicus. General and Comparative Endocrinology, 127:285-292. 
Rousseau K \& Dufour S (2007). Comparative aspects of GH and metabolic regulation in lower vertebrates. Neuroendocrinology, 86:165-174.

RUIJTER JM, RAMAKERS C, HOOGAARS WM, KARLEN Y, BAKKER O, VAN DEN HOFF MJ \& MOORMAN AF (2009). Amplification efficiency:linking baseline and bias in the analysis of quantitative PCR data. Nucleic Acids Research, 37:e45.

Ryder TB, PARKer PG, BlaKe JG \& LOISELle BA (2009). It takes two to tango: reproductive skew and social correlates of male mating success in a lek-breeding bird. Proceedings of the Royal Society B: Biological Sciences, 276:2377-2384.

SAPOLSKY RM (2005). The influence of social hierarchy on primate health. Science, 308:648652.

Silverstein JT, SHEARER KD, DickHOFF WW \& PLISETSKAYA EM (1998). Effects of growth and fatness on sexual development of chinook salmon (Oncorhynchus tshawytscha) parr. Canadian Journal of Fisheries and Aquatic Sciences, 55:2376-2382.

STEFÁNSSON MÖ, IMSLAND AK, JENSSE MD, JONASSEN TM, STEFANSSON SO \& FITZGERALD $R$ (2000). The effect of different initial size distributions on the growth of Atlantic halibut. Journal of Fish Biology, 56:826-836.
VERA CRUZ EM \& BROWN CL (2007). The influence of social status on the rate of growth, eye color pattern and insulin-like growth factor-I gene expression in Nile tilapia, Oreochromis niloticus. Hormones and Behavior, 51:611-619.

VERA CRUZ EM \& BROWN CL (2009). Influence of the photoperiod on growth rate and insulin-like growth factor-I gene expression in Nile tilapia Oreochromis niloticus. Journal of Fish Biology, 75:130-141.

WaTANABE $\mathrm{M}$, TAKAMURA $\mathrm{S}$ \& MAEKAWA $\mathrm{K}$ (2008). Effects of timing of nest entry and body size on the fertilization success of alternative male reproductive phenotypes of masu salmon (Oncorhynchus masou). Canadian Journal of Zoology, 86:1121-1130.

WOOD AW, DuAN C \& Bern HA (2005). Insulinlike growth factor signaling in fish. International Review of Cytology, 243:215-285.

Received: 19 June 2014

Accepted: 15 September 2014

Branch editor: Roger Huybrechts 